\title{
Integration of the LIDAR data and bathymetric measurements in the assessment of water resources and morphometric parameter changes - based on Lake Kiedrowickie
}

\author{
Adam Piasecki, Rajmund Skowron \\ Department of Hydrology and Water Management, Faculty of Earth Sciences, Nicolaus Copernicus University in Toruń, Lwowska 1, \\ 87-100 Toruń, Poland, e-mail: piasecki@doktorant.umk.pl (corresponding author); rskowron@umk.pl
}

\begin{abstract}
The aim of this paper was to present the possibility of integrating LIDAR data with bathymetric measurements in order to assess the changes in water resources and morphometric parameters. The area of study was Lake Kiedrowickie (Poland). A change in most of the morphometric parameters has been observed. Especially important was the drop in water resources which amounted to more than $30 \%$. A significant decrease (13.4\%) was also observed in case of the lake surface. In conclusion we state that the integration of valid bathymetric measurements with the LIDAR data gives the full capability to model the changes of lake morphometric parameters with unprecedented accuracy. A significant complementarity and synergy of applying both techniques has been stressed.
\end{abstract}

Key words: aerial laser scanning, lake morphometry, bathymetric map

\section{Introduction}

As an element of the environment, lakes undergo dynamic qualitative (water chemical composition) and quantitative (water resources, water level, shape of lake basin recasting) changes. From their origin lakes are the object of continuous evolution, which in the final stage leads to their disappearance. Initially the pace of disappearance was determined only by natural conditions, mainly climate fluctuations. Dynamic population growth in the $20^{\text {th }}$ century, combined with the intensification of agriculture and industrial development, led to stronger anthropopression. This has a severe impact on water ecosystems, including lakes. Human interference in the natural environment hastened the process of the disappearance of lakes in many parts of the world (Marszelewski 2005; Kowalczewska-Madura and Gołdyn 2006; Søndergaard and Jeppesen 2007; Corella et al. 2011).

Morphometric recognition of lake basins is one of the basic tasks in the field of limnology. The shape and area of a reservoir have a decisive impact on the course of many phenomena and processes in lakes. They also determine its biotic and abiotic features. Awareness of lake morphometry and of the dynamics of its changes is essential when it comes to solving limnological tasks. It is also of great importance in the area of biological and geomorphological research (Hutchinson 1957; Hollister and Milstead 2010). The primary sources of information in this area are bathymetric plans. Juxtaposition of two bathymetric plans elaborated over a relatively long spell (at least several dozen years) enables us to determine the changes in the lake bottom and its morphometric parameters. It can also provide essential information on the evolution of vegetation in the coastal zone (Skowron and Piasecki 2014).

Unfortunately there is only an unusually rare possibility to perform comparative studies of data and current bathymetric plans. It results from the limited number of this kind of research papers. In the assessment of quantitative changes in lakes old maps (above all topographical ones) are remarkably helpful. They enable researchers, with a relatively great accuracy 
(the condition is a large map scale) and ease, to calculate the change in lake surface and water surface elevation. In an approximate way it is also possible to determine the volume of water. Nowadays due to modern research tools we are capable of determining more precisely the changes in the above-mentioned elements. Of great importance is the possibility of applying aerial laser scanning LIDAR (Light Detection and Ranging).

The LIDAR data have so far been applied in many fields of science such as earth sciences, archaeology, engineering, ecology and biology (Baillard 2004; Pitkänen et al. 2004; Hesse 2010; Wojciechowski et al. 2012). Among the unquestionable advantages of this data source one may include the high accuracy of the data obtained and the relatively short period of time needed for their processing and preparation. However, the method of aerial laser scanning does not come without disadvantages such as absorption of laser impulses by clouds, fog, water, asphalt or tar, as well as the large volume of processed data (Wężyk 2006). Not without significance are issues related to the high cost of data acquisition.

The aim of this paper was to present the possibility of applying the LIDAR data to assess the changes in water resources and morphometric parameters of lakes. This study has been conducted on the basis of a lake located in Northern Poland.

\section{Study area}

For testing Lake Kiedrowickie, located in Northern Poland near the town of Bytów within the area of Charzykowy Plain, was selected. It is a small, endorheic, post-glacial, lobelia lake (Krasko 1996). The lake is supplied with water mainly from rainfall and probably from an underground water inflow. An island is located in the north-eastern part of the lake. It is a nesting site for species of birds abundant here (Fig. 1).

The analysed area is located in a temperate climate which is characterized by a high variability, resulting from a meeting of oceanic and continental air masses. The average annual sum of rainfall over the period of 1980-2013 amounted to $590 \mathrm{~mm}$, with a mean temperature of $7.7^{\circ} \mathrm{C}$.

The lay of the land is dominated by an accumulation plain of glacial meltwater, built with glaciofluvial sands. The region is diversified by deep lake basins here and there, originating from ice blocks covered by sand during the last glaciation.
The scrutinized lake is situated in a hollow surrounded by rather low hills, determining the area of its catchment, which is slightly above $4.35 \mathrm{~km}^{2}$. In its western part it is used as arable land and in the northern and eastern it is overgrown by forests, mainly pinewoods. In the south-western part of the catchment, a minor settlement Kiedrowice, with a population of 240 , is located.

\section{Materials and Methods}

In this work data from filed bathymetric measurements performed with fixed water surface elevation were used. The measurements were done during late autumn (November 2014), in order to minimalize the vegetation impact on the quality of the results. Lake depth was estimated based on an echo sounder integrated with a GPS receiver. Measurements were performed according to the following methodology:

Circumnavigation of the whole lake, as close to the shoreline as possible. The island was measured in a similar way. Thereby it was possible to acquire accurate data on the shallowest part of the lake - the littoral zone.

Crossing the lake concordantly with previously marked out routes 10 metres away from each other.

The water level was estimated based on measurements made by a GPS Topcon - HiperPro receiver. The determined coordinates were corrected by means of DGNSS (Differential Global Navigation Satellite System) corrections from the TPI NET network.

In this work data from aerial scanning performed in the year 2012 were used as well. Data were in the form of a text file, containing coordinates $(\mathrm{X}, \mathrm{Y}, \mathrm{Z})$ of points, deployed on a regular grid with a 1 metre resolution, interpolated from a cloud of points from aerial laser scanning (LIDAR). The mean error was about 0.2 metres (CODGiK 2012).

The water level measured by means of aerial laser scanning was different from that obtained from bathymetric measurements by 0.2 metres. Hence it was necessary to introduce corrections to the measured depths by the mentioned value. Information about the water level from different periods was also obtained.

Results of bathymetric measurements and LIDAR data enabled us to create a numerical model of the lake basin and its coastal zone. The next step was to determine morphometric parameters including lake surface and water volume for the highest and 


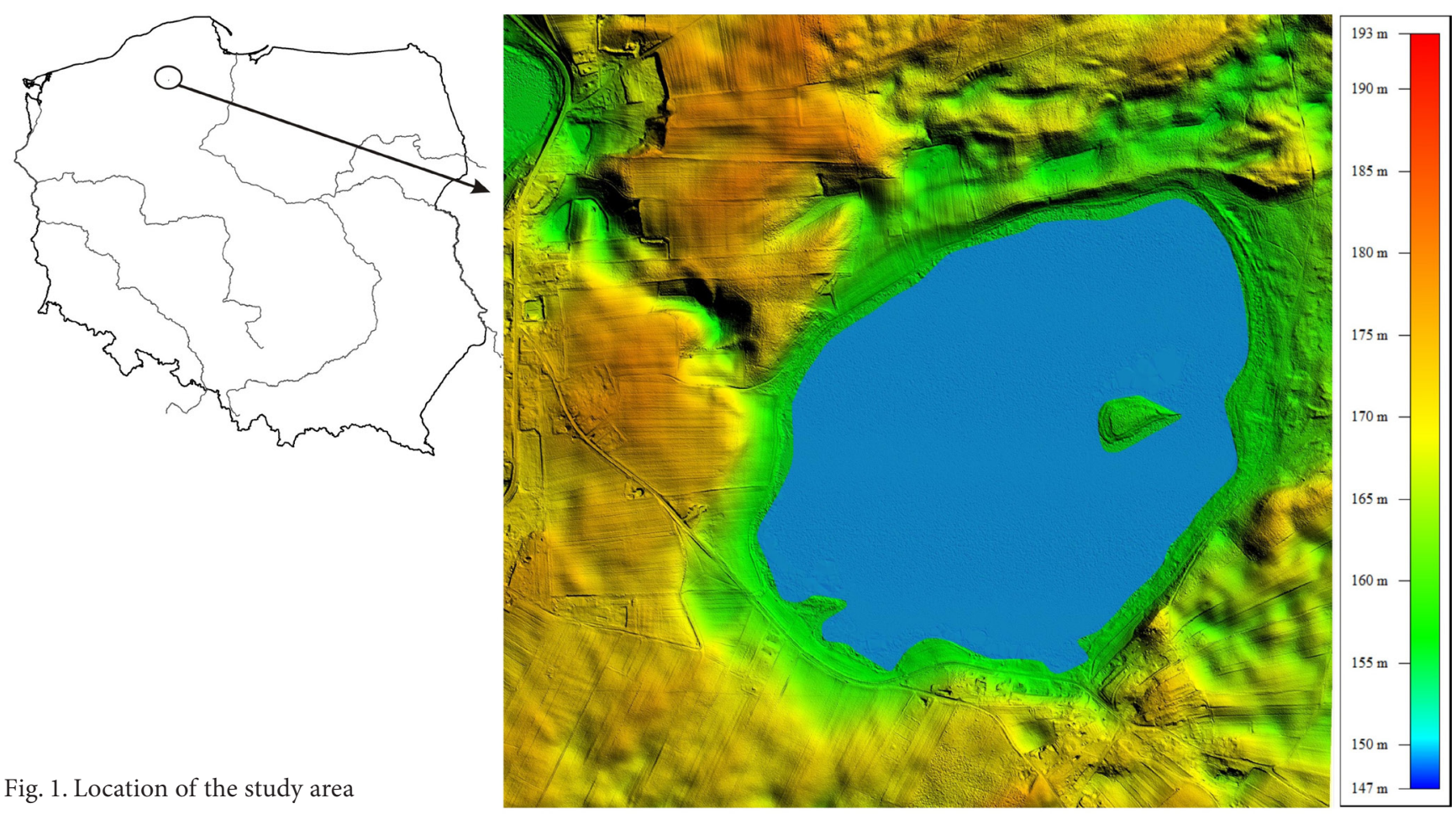

lowest recorded water level. All changes in parameters are related to the highest observed water level known further as the reference level.

\section{Results and Discussion}

The bathymetric plan, created based on field research, indicated a high differentiation in Lake Kiedrowickie's basin shape. Its western part is the shallowest one, with depths to about 3 metres. There is an increase in depths in the north-eastern direction. The deepest point (7.5 metres) of the lake is located not far to the west of the island. In the eastern part the depths are much greater; the distances between isobaths are rather small but highly disturbed (Fig. 2).

The highest recorded water level in the analysed lake was observed in the year 1874 and amounted to 165.5 metres a.s.l. The next level equal to 155.1 metres a.s.l. is from March 1964. It was estimated as part of the bathymetric measurements performed by the Institute of Inland Fishing in Olsztyn. A similar water level can be found on a topographic map (at scale 1:10 000) from the mid-1980s. During the measurements performed in October 2014 the water level was equal to 154.9 metres a.s.l.
Based on a numerical model of the lake basin along with the shore zone we conducted a simulation of morphometric parameter changes for each of the above-mentioned water levels. Such models were created before LIDAR-data were commonly accessible; however, they were characterized by a much lower accuracy. Most frequently they were made on the basis of digitalized contours of topographic maps at scale 1:10 000 (Rzeszewski et al. 2008). Integration of LIDAR data and bathymetric measurements enables us to model changes occurring in lakes with hitherto unknown accuracy.

The results obtained indicate a clear change in the value of most morphometric parameters. Particularly important is the drop in the amount of water resources, which amounts to over $30 \%$. A significant decrease was also observed in the case of water surface area, which dwindled by $13.4 \%$, but this can be associated with the small declination angle of the coastal zone. Along with decreasing lake water level the depth declined as well. It should be noted that in this research the natural process of sedimentation and sedentation which make a lake shallower were not considered. According to the literature the annual gain in sediment thickness as a result of the above mentioned 
Fig. 2. Bathymetric map of Lake Kiedrowickie

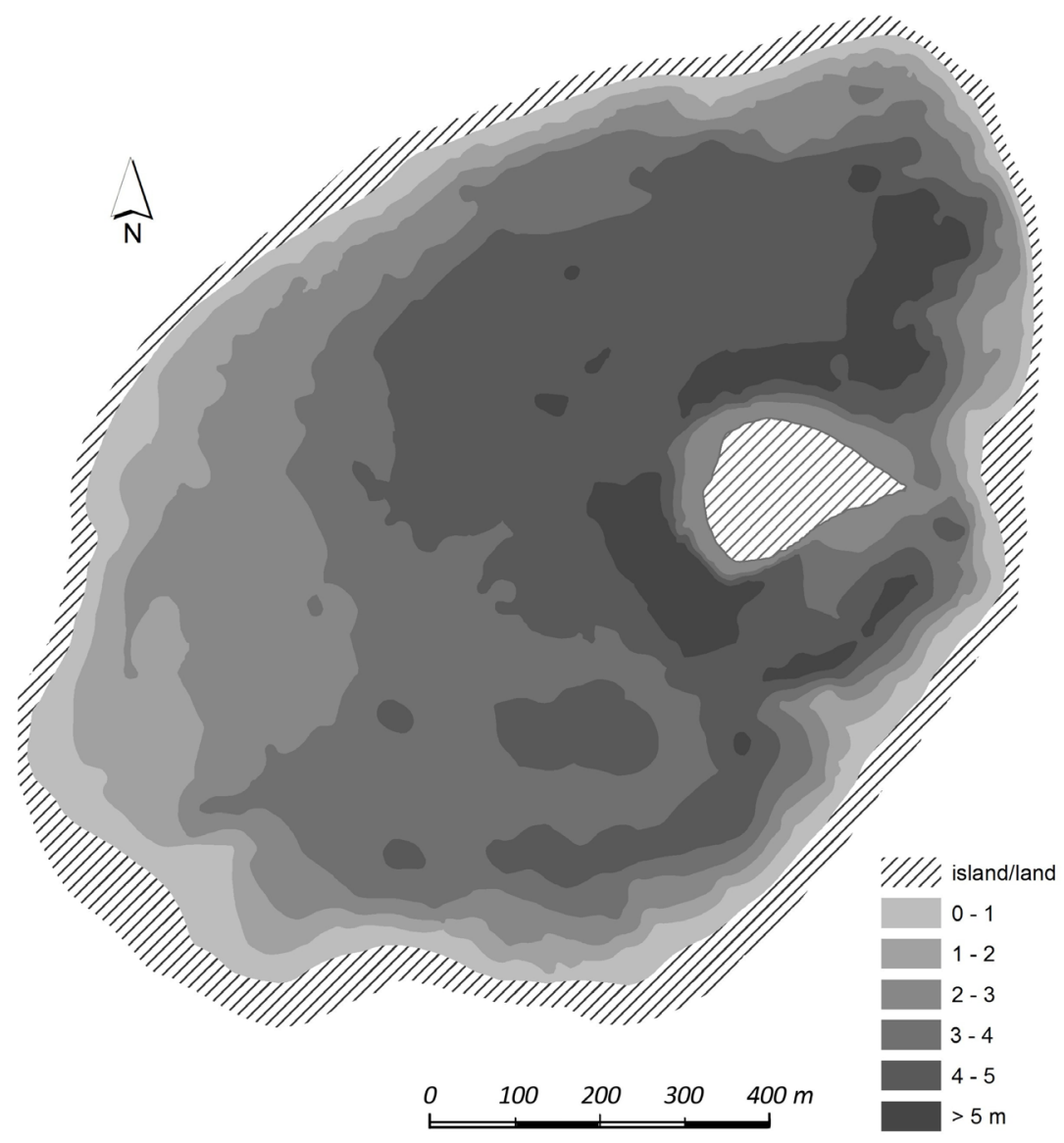

process amounts to between 0.5 and $2.0 \mathrm{~mm}$ (Żurek 1996; Bogaczewicz-Adamczak et al. 2002). However, in individual lakes these values may be significantly greater than a few millimetres per annum (Federowicz et al. 2002; Tylman 2003). Nevertheless in the case of the investigated lake the gains in terms of sediment thickness were rather low due to the fact that the lake is supplied from a direct catchment. Other detailed results concerning selected morphometric parameters at the determined water level are presented in Table 1.

Application of LIDAR data in the described area of limnology seems to be necessary and of great importance. Due to their usage the speed and accuracy of the results obtained is much greater. But one must bear in mind that there are some constraints when it comes to the application of LIDAR data. Constraints are related mainly to the differences in water level while bathymetric and aerial measurements were carried out in different time periods. Another issue is the fact that aerial scanning was performed in Poland during the vegetation period, which led to a decrease in accuracy for areas with thick flora. However, here additional research is needed to determine the range of error. The application of LIDAR data may be limited when there is a backflow just before the aerial scanning procedure. This results from the fact that it is not possible to restore the range of the lake before backflow. However, the current water fluctuations can be modelled. In addition it is worth mentioning that only a part of the country has been scanned.

Integration of present bathymetric measurements and LIDAR data gives a complete opportunity to model the changes of morphometric lake parameters. It happens that when there is no bathymetric plan created by means of modern methods (echo sound integrated with a GPS receiver) old ones are used. In Poland plans created by the Institute of Inland Fishing in the 1950s and 60s are used most frequently. When such plans are used it can be debated whether they guarantee accurate numerical models of the lake basin. It is problematic to give those plans a georeference because they do not have any spatial orientation. 
Table 1. Morphometric parameters and indices of Lake Kiedrowickie

\begin{tabular}{|c|c|c|c|c|}
\hline \multirow{2}{*}{ Parameter / Index } & \multirow{2}{*}{ Symbol / Formula } & \multicolumn{2}{|c|}{ Water level } & \multirow{2}{*}{$\begin{array}{c}\text { Difference } \\
{[\%]}\end{array}$} \\
\hline & & 156.5 [m a.s.l] & 154.9 [m a.s.l] & \\
\hline Surface area [ha] & A & 107.2 & 92.8 & -13.4 \\
\hline Surface area of islands [ha] & $A_{i}$ & 1.5 & 2.2 & 17.0 \\
\hline Volume [dam $\left.{ }^{3}\right]$ & V & 4508.84 & 3082.47 & -31.6 \\
\hline Maximum length [m] & $\mathrm{L}_{\max }$ & 1410 & 1340 & -1.7 \\
\hline Maximum width [m] & $\mathrm{W}_{\max }$ & 974 & 956 & -1.8 \\
\hline Elongation & $\lambda=\mathrm{L}_{\max } / \mathrm{W}_{\max }$ & 1.45 & 1.40 & -0.2 \\
\hline Mean width [m] & $\mathrm{W}_{\text {mean }}=\mathrm{A} / \mathrm{L}_{\max }$ & 760.28 & 692.54 & -9.3 \\
\hline Shoreline length [km] & SL & 3.96 & 3.9 & -1.5 \\
\hline Shoreline development & $\mathrm{SD}=\mathrm{SL} / 2(\pi \mathrm{A})^{0.5}$ & 1.08 & 1.14 & 5.9 \\
\hline Maximum depth [m] & $\mathrm{D}_{\max }$ & 8.9 & 7.5 & -15.7 \\
\hline Mean depth [m] & $\mathrm{D}_{\text {mean }}=\mathrm{V} / \mathrm{A}$ & 4.21 & 3.32 & -21.0 \\
\hline Depth indicator & $W g=D_{\text {mean }} / D_{\max }$ & 0.47 & 0.44 & -6.3 \\
\hline
\end{tabular}

\section{Conclusion}

Integration of LIDAR data with current bathymetric measurements seems to indicate a correct direction in the modern approach to the analysis of water resources and geometry of lake basins. It is important to highlight a significant complementarity and synergy when both those techniques of data acquisition are applied. A numerical model of the lake basin created on their basis provides a full opportunity to analyse and simulate the changes in water resources and morphometric parameters when the water level changes. In this paper, we have presented the possibility of combining these two techniques based on Lake Kiedrowieckie. The nature of the changes which occurred within the range of the selected parameters and indices characterizing the investigated lake in terms of its geometry and specified properties has been assessed as negative. The scale of the change in individual parameters was different. The greatest recast appeared in the case of water resources, surface and depth of Lake Kiedrowickie. These processes are strongly influenced by the initial lake basin and the shape of the adjacent area. At this stage it is impossible to unequivocally state what sort of factors led to such a significant decrease in water level. Therefore further research in this area is being planned, which will determine not only the causes but possible directions of future transformation.

What is more, we have pointed out the limitations when it comes to the application of the LIDAR data. In the case of each lake it is important to verify whether it is possible to apply this technique. The ease, speed and accuracy of the results obtained seem to prejudge in favour of aerial scanning measurements in the field of limnology. It is important to mention that this technology is undergoing a process of continuous improvement, so the results obtained can be only better.

\section{References}

Baillard C., 2004, Production of DSM/DTM in urban areas: role and influence of 3D Vectors, Int. Arch. Photogram. Rem. Sens. Spatial Inform. Sci. 35(3): 112-117.

Bogaczewicz-Adamczak B., Noryśkiewicz B., Wegrzyn-Stachura J., 2002, Environmental changes of Lake Biskupin in late Holocene on the basis of palaeoecological research (the last 4.300 years), Limnol. Rev. 2: 29-37.

Corella J. P., El Amrani A., Sigró J., Morellón M., Rico E., Valero-Garcés B. L., 2011, Recent evolution of Lake Arreo, northern Spain: influences of land use change and climate, J. Paleolimnol. 46(3): 469-485. 
Hesse R., 2010, LiDAR-derived Local Relief Models - a new tool for archaeological prospection, Archaeological Prospection 17(2): 67-72.

Hollister J., Milstead W.B., 2010, Using GIS to estimate lake volume from limited data, Lake Reserv. Manage. 26(3), 194-199.

[CODGiK] Centralny Ośrodek Dokumentacji Geodezyjnej i Kartograficznej (Central Documentation Centre of Geodesy and Cartography)), 2012, Numeryczne dane wysokościowe (Numerical elevation data). Retrieved from: http://www.codgik.gov.pl/index.php/zasob/numeryczne-dane-wysokosciowe.html.

Hutchinson G.E., 1957, A Treatise on Limnology. Vol. 1: Geography, physics, chemistry, John Willey, New York, pp. 1015.

Kowalczewska-Madura K., Gołdyn R., 2006, Anthropogenic changes in water quality in the Swarzędzkie Lake (West Poland), Limnol. Rev. 6: 147-154.

Marszelewski W., 2005, Zmiany warunków abiotycznych w jeziorach Polski północno-wschodniej (Changes of the abiotic conditions in the lakes of north-east Poland), Wydaw. UMK, Toruń, pp. 288 (in Polish, English summary).

Melzer T., Briese Ch., 2004, Extraction and modeling of power lines from ALS point clouds, [in:] Proc. of the 28th Austrian Assoc. Pattern Recog. Workshop, 17-18 June, Hagenberg: 47-54.

Pitkänen J., Maltamo M., Hyyppä J., Yu X., 2004, Adaptive methods for individual tree detection on airborne laser based canopy height model, Int. Arch. Photogram. Rem. Sens. Spatial Inform. Sci. 36(8): 187-191.
Rzeszewski M., Jasiewicz J., 2008, Konstrukcja cyfrowych modeli rzeźby na obszarach problemowych w strefie wybrzeża (Construction of digital relief models on the problem areas in the coastal zone), [in:] Rotnicki K., Jasiewicz J., Woszczyk M., (ed.), Holoceńskie przemiany wybrzeży i wód południowego Bałtyku - przyczyny, uwarunkowania i skutki (Holocene transformations of coastlands and the Southern Baltic waters - causes, conditions and consequences), Wydaw. Nauk. UAM, Poznań, 113-118 (in Polish).

Skowron R., Piasecki A., 2014, Overgrowth of lakes as an indicator of their disappearance-on the example of the lakes of north-western Poland, [in:] Proc. of the 2nd International Conference Water resources and wetlands, 11-13 September, Tulcea: 94-101.

Søndergaard M., Jeppesen E., 2007, Anthropogenic impacts on lake and stream ecosystems, and approaches to restoration, J. Appl. Ecol. 44(6), 1089-1094.

Tylman W., 2003, Reliability of dating recent lake sediments as an indicator of 20th century pollution: Case study on Lake Jasień, Limnol. Rev. 4: 255-260.

Wężyk P., 2006, Wprowadzenie do technologii skaningu laserowego w leśnictwie (Introduction to laser scanning technology in forestry), Rocz. Geomatyki 4(4), 119-132 (in Polish, English summary).

Wojciechowski T., Borkowski A., Perski Z., Wójcik A., 2012. Dane lotniczego skaningu laserowego w badaniu osuwisk - przykład osuwiska w Zbyszycach: Karpaty zewnętrzne (Airborne laser scanning data in landslide studies at the example of the Zbyszyce landslide: Outer Carpathians), Prz. Geol. 60: 95-102 (in Polish, English summary).

Żurek S., 1996, Wiek torfowisk i jezior w świetle datowań radiowęglowych (Age of bogs and lakes in the light of radiocarbon dating), Zesz. Nauk. PŚl. 80(14): 59-77 (in Polish). 